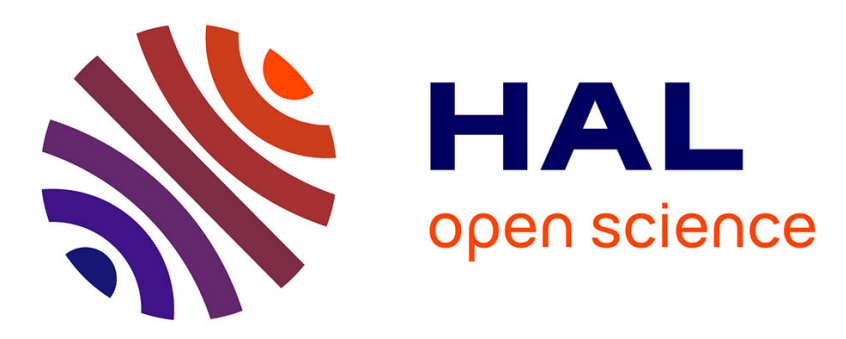

\title{
Physico-chemical characteristics of topsoil for contrasted forest, agricultural, urban and industrial land uses in France
}

Sophie Joimel, Jerome Cortet, Claudy C. Jolivet, Nicolas Saby, Elodie-Denise Chenot, Philippe Branchu, Jean-Noël Consalès, Clémence Lefort, Jean-Louis Morel, Christophe Schwartz

\section{To cite this version:}

Sophie Joimel, Jerome Cortet, Claudy C. Jolivet, Nicolas Saby, Elodie-Denise Chenot, et al.. Physicochemical characteristics of topsoil for contrasted forest, agricultural, urban and industrial land uses in France. Science of the Total Environment, 2016, 545, 10.1016/j.scitotenv.2015.12.035 . hal-01260994

\section{HAL Id: hal-01260994 https://hal.science/hal-01260994}

Submitted on 22 Jan 2016

HAL is a multi-disciplinary open access archive for the deposit and dissemination of scientific research documents, whether they are published or not. The documents may come from teaching and research institutions in France or abroad, or from public or private research centers.
L'archive ouverte pluridisciplinaire HAL, est destinée au dépôt et à la diffusion de documents scientifiques de niveau recherche, publiés ou non, émanant des établissements d'enseignement et de recherche français ou étrangers, des laboratoires publics ou privés. 


\title{
Physico-chemical characteristics of topsoil for contrasted forest, agricultural, urban and industrial land uses in France
}

\author{
S. Joimel ${ }^{\mathrm{a}, \mathrm{b}}$, J. Cortet $^{\mathrm{c}}$, C.C. Jolivet ${ }^{\mathrm{d}}$, N.P.A. Saby ${ }^{\mathrm{d}}$, E.D. Chenot ${ }^{\mathrm{a}, \mathrm{b}}$, P. Branchu $^{\mathrm{e}}$, J.N. Consalès ${ }^{\mathrm{f}}$, C. Lefort ${ }^{\mathrm{a}, \mathrm{b}}$, \\ J.L. Morel ${ }^{\mathrm{a}, \mathrm{b}}, \mathrm{C}$. Schwartz ${ }^{\mathrm{a}, \mathrm{b}, *}$ \\ a Université de Lorraine, Laboratoire Sols et Environnement, UMR 1120, TSA 40602, F-54518 Vandœuvre-lès-Nancy, France \\ b INRA, Laboratoire Sols et Environnement, UMR 1120, TSA 40602, F-54518 Vandœuvre-lès-Nancy, France \\ ' UMR CEFE 5175, Université de Montpellier, EPHE, Université Paul-Valéry Montpellier, F-34199 Montpellier Cedex, France \\ d INRA, US 1106 Infosol, F-45075 Orléans Cedex 2, France \\ e Cerema Unité Qualité des Eaux et des Sols, Direction territoriale Ile de France, F-78190 Trappes, France \\ ${ }^{\mathrm{f}}$ Université Aix-Marseille, UMR 7303, TELEMME, CNRS, Aix-en-Provence, France
}

\section{H I G H L I G H T S}

- A database of caracteristics of 2451 topsoils representative for France is analysed.

- Human activities increase metal contamination along an anthropisation gradient.

- Total $\mathrm{Cu}, \mathrm{Pb}, \mathrm{P}_{\mathrm{Olsen}}$ and $\mathrm{pH}$ are indicators of soil quality discriminated by land use.

\section{G R A P H I C A L A B S T R A C T}

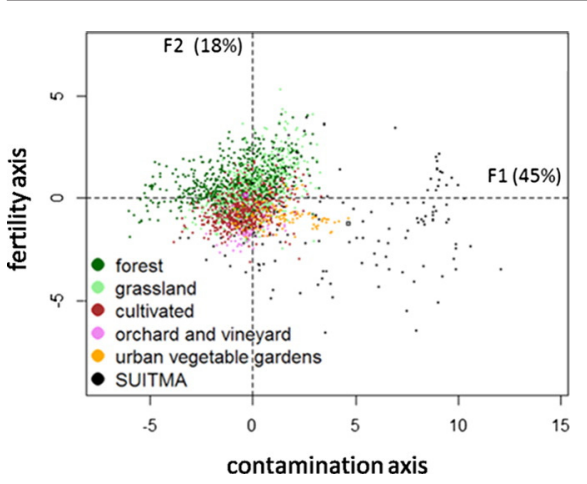

A B S T R A C T

Soil quality is related to soil characteristics such as fertility and contamination. The aim of this study is to assess the effect of land use on these soil characteristics and to confirm the following anthropisation gradient: (i) forest, (ii) grassland, (iii) cultivated, (iv) orchard and vineyard, (v) urban vegetable garden, and (vi) SUITMA (urban, industrial, traffic, mining and military areas). A database comprising the characteristics of 2451 soils has been constituted. In order to compare the topsoils from six contrasting land uses, a principal components analysis (PCA) was performed on nine geochemical variables $\left(\mathrm{C}, \mathrm{N}, \mathrm{pH}, \mathrm{P}_{\mathrm{Olsen}}\right.$, total $\left.\mathrm{Cd}, \mathrm{Cu}, \mathrm{Ni}, \mathrm{Pb}, \mathrm{Zn}\right)$. The first axis of the PCA is interpreted as a global increase of topsoil metallic elements along the anthropisation gradient. Axis 2 reflects the variability of fertility levels. Human activity increases the pressure on soils along the proposed gradient according to six different distribution patterns. This better knowledge of topsoil quality and its dependence on current land use should therefore help to manage and preserve the soil mantle.

(c) 2015 Elsevier B.V. All rights reserved.

\section{Keywords:}

Grassland soils

Cultivated soils

Garden soils

Fertility

Contamination

Multivariate analysis

\footnotetext{
* Corresponding author at: Université de Lorraine, Laboratoire Sols et Environnement, UMR 1120, TSA 40602, F-54518 Vandœuvre-lès-Nancy, France. E-mail address: christophe.schwartz@univ-lorraine.fr (C. Schwartz).
} 


\section{Introduction}

The quality of a soil is defined as its ability to fulfill functions and provide ecosystem services (Morel et al., 2014). Anthropisation, which designates an effect resulting from "human activity" (El Khalil et al., 2013), is often described as the main driver of ecosystem modifications (Vitousek et al., 1997), especially for biotopes like soil. The fertility level and contamination of soils are generally considered to be two aspects of soil quality. The modifications of the soil characteristics are dependent on the human use of land. Land use concerns the products and/or benefits obtained from use of the land, as well as the land management carried out by humans to produce those products and benefits (Ellis and Pontius, 2012). In this study, we will employ the term "land use" to describe the main type of human activity in each area. Land use involves the management and the modification of the natural environment through cultivation, urbanisation or industrialisation (El Khalil et al., 2013), which differ with the intensity and the duration of human impact (Morel et al., 2005a, 2005b). Urban soils differ from those in rural areas by the scale and intensity of human impacts on soils (Bullock and Gregory, 1991). Agriculture and forestry are often considered as having little disturbing effects on soil, whereas urban and industrial activities could potentially involve organic and inorganic pollution causing a significant alteration of physical, geochemical, and biological properties (Norra et al., 2006; Schwartz et al., 2001). In previous studies, Cd and $\mathrm{Pb}$ contaminations were often observed in community gardens or kitchen gardens (Douay et al., 2008; Mitchell et al., 2014). Urban soils are often characterised by high $\mathrm{pH}$ values as well as a large amount of coarse materials and soil organic matter, which influence porosity dynamics (Nehls et al., 2006). Therefore, all land uses do not have the same effect on soil quality. These effects vary in function of the frequency and intensity of corresponding human activities. Also, the ability of soils to provide such functions as vegetation and biodiversity support, filter and exchange, is modified by land use. However, to our present knowledge, no study has explored how a complete range of contrasting land uses influences topsoil chemistry. Saby et al. (2009) and Arrouays et al. (2011) have investigated the spatial patterns of the topsoil characteristics, but their work mainly focused on forest, agriculture and permanent crops. In contrast, the aim of this work is to establish the status of topsoil quality and its factors throughout France along an original land use gradient. According to the differences in intensity and frequency of human activities, we propose to test the existence of a soil anthropisation gradient from forest-grassland-cultivated-orchard and vineyard-vegetable urban garden to SUITMA (urban, industrial, traffic, mining and military areas). SUITMA are the ultimate members of a continuum characterised by increasing human influence, ranging from soils not or only slightly affected by human influence to agricultural lands to urban soils where the human imprint is maximum and where natural features have often disappeared (De Kimpe and Morel, 2000). The SUITMA group comprises soils used for the mining industry, solid and liquid waste dumping, as well as habitation and road construction. It should also be mentioned that garden soils are excluded here from the SUITMA category and constitute a separate land use. Indeed, there is no consensus about garden soils, which are often considered as cultivated soils with intensive management (e.g. McDonald and Balasko, 2003). For this study, rural gardens, rural market gardens, ornamental gardens and kitchen gardens have been skipped, and thus only urban vegetable garden soils from allotments have been considered.

Thanks to the existence of the national soil quality monitoring network based on a systematic grid over the entire French metropolitan territory (RMQS), the French national survey of garden soils (JASSURANR) and data collected over 20 years on SUITMAs at the LSE research unit (Laboratoire Sols et Environnement, UMR 1120 University of Lorraine-INRA) (Lefort, 2009; Lefort et al., 2006), a comparative study of topsoil characteristics ( $\mathrm{pH}$, carbon $(\mathrm{C})$ and nitrogen $(\mathrm{N})$, available phosphorus ( $\left.\mathrm{P}_{\mathrm{Olsen}}\right)$, and total trace metals) is put forward to assess the anthropisation gradient, using a multivariate statistics methodology. Our objective is to confirm the increase in total element concentration with the intensification of human activities along an anthropisation gradient. As for the fertility parameters in agricultural soils, two possibilities are considered: (i) an increase due to the use of fertilisers for plant biomass production, or (ii) a decrease induced by cultivation. We also hypothesise that even though the different data sets have quite distinct distributions, it is feasible to handle and interpret soil data in order to obtain further knowledge about soil quality depending on land use. The global characteristics of French topsoils will be discussed and compared according to land uses, without accurate agronomic interpretations and without taking into account successive land uses at a given point. The resulting implications for the development of soil quality indicators and for the management of French soils according to land use, will be discussed.

\section{Materials and methods}

The data pertain exclusively to the characteristics of topsoils (up to $30 \mathrm{~cm}$ ) and do not concern deeper layers of soil profiles. The proposed gradient refers to varying land use: forest-grassland-cultivated-orchard and vineyard-urban vegetable garden-SUITMA (urban, industrial, traffic, mining and military areas). The first five land uses proposed in this gradient are exclusively dedicated to plant growth, although the last land use includes several human activities which could possibly impact plant biomass production.

\subsection{Soil characteristic dataset}

The dataset of 2451 topsoils has been built by gathering together data collected in the framework of distinct research programs carried out with different sampling strategies (Table 1). The different sampling approaches were developed in order to collect soil samples representative of French soils.

\subsection{RMQS}

The RMQS database (Arrouays et al., 2002) primarily consists of 2146 observations of soil properties on a $16-\mathrm{km}$ regular grid across the $550,000 \mathrm{~km}^{2}$ French metropolitan territory. If it was not possible to sample the selected site (e.g. in urban areas, in rivers or on roads) an alternative adjacent cultivated or undisturbed location within a 1$\mathrm{km}$ radius was selected. Where this was not possible, the cell was omitted from the survey. This baseline survey of the RMQS was completed in 2009. At each site, 25 individual core samples were taken from the topsoil $(0-30 \mathrm{~cm})$ layer, using an unaligned sampling design within a $20 \times 20$-m area. The $0-30 \mathrm{~cm}$ layer was chosen to ensure consistency with existing surveys and because in France $30 \mathrm{~cm}$ is the maximum depth at which topsoil is generally affected by plowing. Core samples were bulked to obtain a composite sample for each site.

\subsection{Garden soil database: JASSUR research program}

The garden soils database exclusively concerns vegetable gardens from allotment sites. An allotment site contains several gardens, each

Table 1

Main features of collected soils.

\begin{tabular}{llc}
\hline Research program & Land use & Number of sampling points \\
\hline RMQS & Forest & 582 \\
RMQS & Agriculture-grassland & 623 \\
RMQS & Agriculture-cultivated & 820 \\
RMQS & Orchard and Vineyards & 48 \\
JASSUR & Urban vegetable gardens & 104 \\
LSE database & SUITMAs & 274 \\
Total & & 2451 \\
\hline
\end{tabular}


being managed by one gardener. Gardening is a very common practice in many industrialised and developing countries. In France, allotment gardens cover more than 200,000 ha (INSEE, 1993), and many of them are situated at the interface between agricultural, industrial and urban areas (Chenot et al., 2012). Garden soils are soils located in urban, suburban or industrial areas with the purpose of plant biomass production. This variety of locations is entailed by the diversity of gardens and represents a challenge when conducting a systematic data collection (Dewaelheyns et al., 2013). A SOJA-ADEME bibliography (2010), was conducted on gardens soils in order to determine the current state of knowledge and how to study them on the French territory. Garden soils have been considered to be influenced by seven factors (Chenot et al., 2012): urbanisation (e.g. urban, rural, peri-urban) (Schroeder et al., 1987), age and sex of the gardener (INSEE, 1993), gardening practices (Crößman and Wüsteman, 1992; Schwartz, 1993), socioprofessional category of the gardener, types and relative shares of productions, climate and age of the garden (Putegnat, 2001). Among these factors, two are independent of the garden: climate and urbanisation. Allotment sites were selected according to these two independent influence factors of the gardens.

To assess the variability of gardens, allotment sites were chosen from different urban contexts under contrasting climates in order to investigate the range of variation in age, plot size and gardeners. Three urban areas were selected: Marseille, Nancy and its surrounding area and Nantes. Marseille is located in south-eastern France, bordering the Mediterranean Sea. This zone is characterised by a Mediterranean climate with a warm, dry summer surrounded by two wet seasons. The area of Greater Nancy is located in north-eastern France. The climate is semi-continental with a strong thermic contrast between summer and winter. Summers are warm and humid and winters are cold and snowy. Nantes is located in western France, close to the Atlantic Ocean and is characterised by an oceanic climate. There is little contrast between winters, rainy and mild, and summers, cool and humid. Rainfall is low but regular. Inside urban areas, allotments sites were chosen according to land use typology (residential, industrial, semi-natural). This typology was defined considering the level of urbanisation $500 \mathrm{~m}$ around each allotment site based on the annotations of a land cover cartography (prepared using satellite images): Corine Land Cover 2006 Level 3 (Bossard et al., 2000): "Residential", when the site includes more than $70 \%$ artificial areas (for example: continuous or discontinuous building, road, airports); "Industrial", more than $30 \%$ of the surface area is used for industrial purposes, "Mixed", when the area around allotment sites is composed of more than $30 \%$ of semi- natural or natural elements. In total, 104 gardens, belonging to 26 allotments sites, were investigated (36 in Marseille, 33 in Greater Nancy, 35 in Nantes). Twenty subsamples of cultivated topsoils $(0-20 \mathrm{~cm}$ mostly depending on the depth affected by plowing) were collected from the cultivated area of each garden. The elementary samples were mixed and homogenised to obtain one representative sample for each garden.

\subsection{SUITMA database}

The SUITMA database is a compilation of several research programs on Soils of Urban, Industrial, Traffic, Mining and Military Areas carried out over the last twenty years. SUITMAs include soil from mining, liquid or solid waste deposits, roads or dwellings. Data from spontaneous forest developed on brownfield are thus classified in the category of SUITMAs, although the vegetation is typical of a forest. Indeed, the main human activity on this site is for the delivery of industrial steel waste over the last two centuries, thereby explaining its brownfield status. It should also be noted that garden soils are excluded from the SUITMAs category here and form a separate use class. Unlike RMQS databases, SUITMAs do not result from a monitoring study conducted on the French territory scale, but through a design based sampling procedure. Nevertheless, this is the only available database for such anthropogenic soils. These 274 topsoils (mean depth of $30 \mathrm{~cm}$ ) were sampled mostly (58\%) in the Eastern (Lorraine and Champagne-Ardenne) and Northern (Nord-Pas de Calais and Picardie) regions of France. The other soils come from studies conducted in Paris or in the South of France (Midi-Pyrénées, Rhône-Alpes, Lozère).

\subsection{Soil analysis}

2451 soil samples from all the datasets were air-dried, disaggregated and sieved at $2 \mathrm{~mm}$. Soil analysis was performed by a certified laboratory for soil analysis (Laboratoire d'analyse des sols-INRA, Arras, France) according to the following standard methods. The parameters retained for comparison between soils use were: $\mathrm{pH}_{\text {water }}$ (NF ISO 10390), organic carbon (C) and total nitrogen (N) (NF ISO 10694), available phosphorus ( $P_{\text {Olsen }}$ ) for plants (Olsen method; NF ISO 11263), total trace metals after $\mathrm{HF}$ dissolution $(\mathrm{Cd}, \mathrm{Cu}, \mathrm{Ni}, \mathrm{Pb}$ and $\mathrm{Zn}$; extraction $\mathrm{HF}$; NF EN ISO 17294-2, NF ISO 22036).

$\mathrm{C}, \mathrm{N}, \mathrm{pH}$ and $\mathrm{P}_{\text {Olsen }}$ were selected as main indicators of soil chemical fertility and were available data for all the studied databases. These parameters allow assessing the ability of the soil to supply mineral elements for the growth and development of plants. $\mathrm{Cd}, \mathrm{Cu}, \mathrm{Ni}, \mathrm{Pb}$ and $\mathrm{Zn}$ total concentrations inform about the level of contamination by trace elements. They are often related to anthropisation and are representative for toxic and/or nutritive elements.

\subsection{Statistical analysis}

In order to compare topsoils of the six land uses: forest-grasslandcultivated-orchard and vineyard-garden-SUITMA, a principal components analysis (PCA) was performed on geochemical variables. The nine variables used for the PCA were: $\mathrm{C}, \mathrm{N}, \mathrm{pH}, \mathrm{P}_{\mathrm{Olsen}}, \mathrm{Cd}, \mathrm{Cu}, \mathrm{Ni}, \mathrm{Pb}$ and $\mathrm{Zn}$. Secondly, we compared the topsoil characteristics of land uses for each geochemical variable. As geochemical data did not match the basic assumptions of normality and homoscedasticity required for parametric statistics (Wilk-Shapiro test at significant level of $p=0.05$ ), we used the Wilcoxon Rank-Sum test to compare these data. No logmodification has been carried out. All statistics were performed using the "FactoMineR" module of the R software.

The database shows a huge variability, especially for heavy metal contents in SUITMAs. In order to preserve global information, we choose to keep all values from the databases, including outliers. In contrast, this variability involves a log-modification of data for the PCA. On the other hand, as extreme values and arithmetic means are of low significance in this study, this information is not included in the boxplot figure. Likewise, only median or percentiles are discussed in this study.

\section{Results}

\subsection{Multivariate analysis (principal component analysis)}

A principal component analysis was run on log-modified geochemical data (Fig.1). The first two axes represented $63 \%$ of the total variability. Axis 1 accounted for $45 \%$ of total variance and was correlated with $\mathrm{Cd}, \mathrm{Cu}, \mathrm{Ni}, \mathrm{Pb}$ and $\mathrm{Zn}$. This axis represented the increase in topsoil metal concentration. The second axis accounted for $18 \%$ of total variance and was correlated with $\mathrm{C}$ and $\mathrm{N}$ and to a lesser extent with $\mathrm{pH}$, representing soil fertility.

\subsection{Variation of soil fertility parameters}

Total organic C contents were by far the lowest in the orchard and vineyard topsoils with a median value of $0.90 \%$ (Fig.2). The highest $\mathrm{C}_{\text {org }}$ concentrations were measured in the following topsoils: grassland (2.48\%), garden (2.62\%), forest (2.68\%) and SUITMAs (3.73\%). Cultivated topsoils present intermediate values of around $1.49 \%$.

Total $\mathrm{N}$ contents are significantly lower in the orchard and vineyard topsoils with a median value of $0.09 \%$ (Fig.3). Median concentrations 

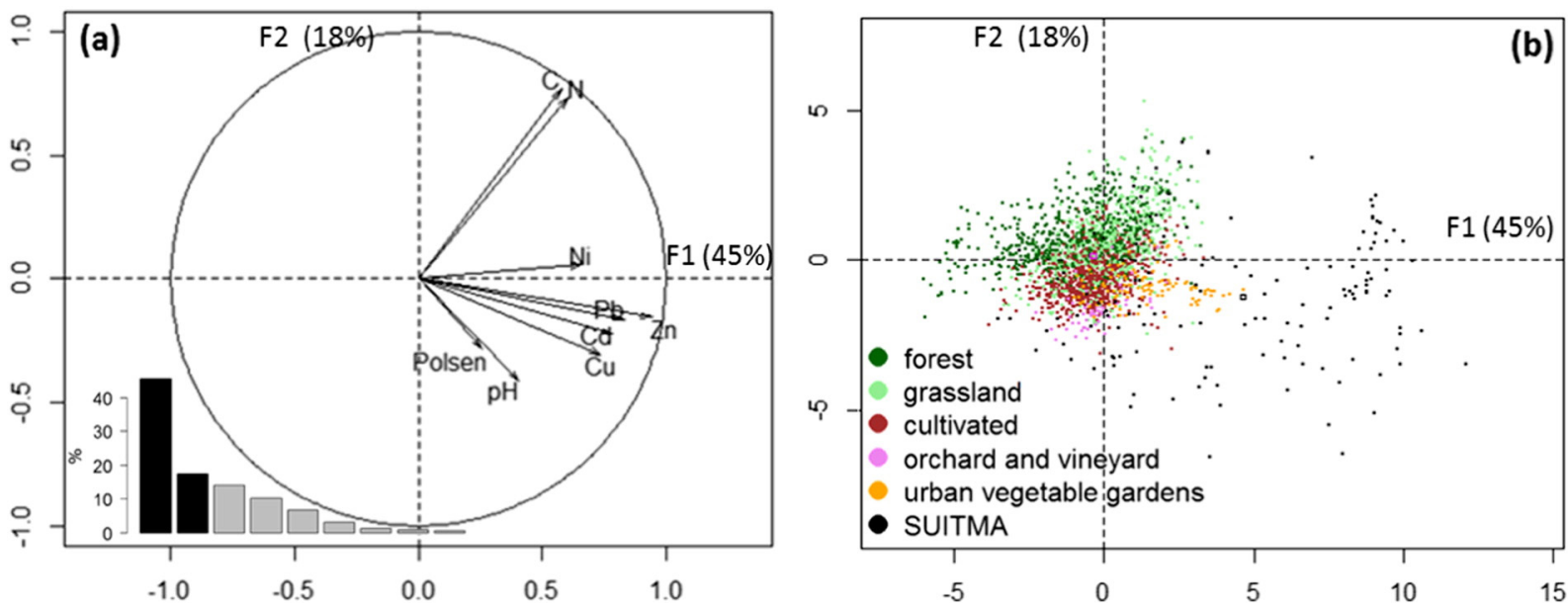

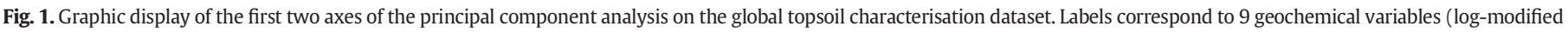

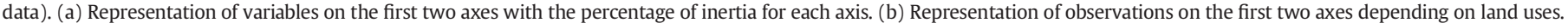

rise from forest $(0.17 \%)$ to gardens $(0.19 \%)$ and to grassland soils $(0.24 \%)$ with significant differences. SUITMAs topsoils have an intermediate median of total $\mathrm{N}$ content $(0.15 \%)$ with no significant differences except for grassland, orchard and vineyard soils.

Significant differences in $\mathrm{pH}$ median were measured with an increase in values along the land use gradient up to orchard and vineyard soils (Fig.4). No significant difference is observable between these soils and SUITMA topsoils. Garden soils exhibit a lower pH median than orchard and vineyard soils. Median values range from 4.9 (forest) to 8.2 (vineyard and orchards). Topsoils are mainly acidic in forests and grasslands, mainly basic in orchards, vineyards, gardens and SUITMAs. Cultivated agricultural topsoils are distributed around neutral $\mathrm{pH}$ values with a median of 7.0 and SUITMAs sometimes present very acidic $\mathrm{pH}$ values with a 95th percentile at 5.4 .

The lowest median concentration of $\mathrm{P}_{\text {Olsen }}$ is measured in forest soils $(0.006 \%)$, while the highest median (30 times the lowest concentration) occurs in garden topsoils (0.183\%) (Fig.5). Two categories of topsoils, grassland $(0.031 \%$ ), orchard and vineyard $(0.035 \%$ ) fall between those extremes and SUITMAs topsoils (0.045\%) constitute an undifferentiated group. Cultivated agricultural soils present significantly higher Polsen concentrations than those from the latter group, but are

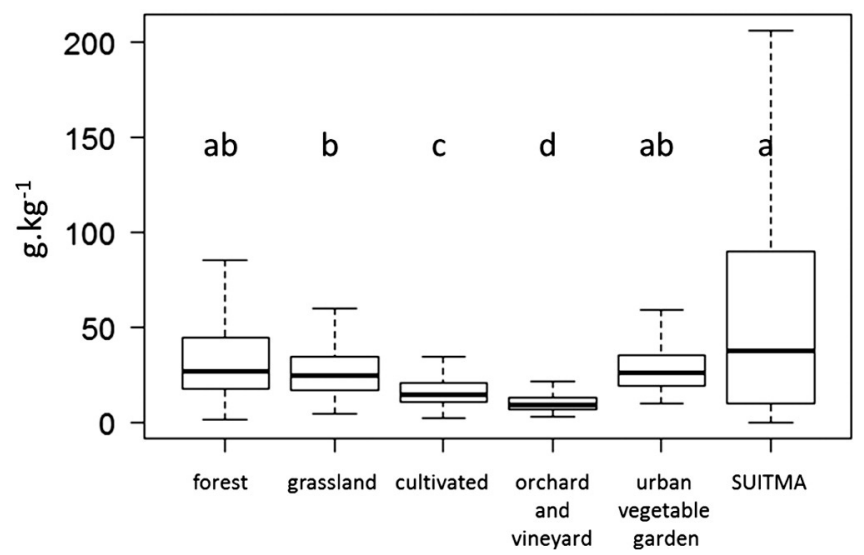

Fig. 2. Distribution of total organic carbon in French topsoils according to land use: forest $(n=582)$, grassland $(n=623)$, cultivated $(n=820)$, orchard and vineyard $(n=48)$, urban vegetable garden $(n=104)$ and SUITMA $(n=229)$. Band inside the box represent the median. Bottom and top of the box are the first and third quartiles. The whiskers indicate the lowest datum within 1.5 interquartile range of the lower quartile, and the highest datum within 1.5 interquartile range of the upper quartile. Lower case letters indicate significant differences between land use. significantly lower than for garden soils. Extremely high values in the 95th percentile have to be mentioned for gardens (0.460\%) and SUITMAs topsoils $(0.455 \%$ ).

\subsection{Soil mineral contamination parameter distribution}

Total Cd concentrations increased along the gradient of land uses, except for orchard and vineyard topsoils (median of $0.18 \mathrm{mg} \cdot \mathrm{kg}^{-1}$ ) (Fig.6). The median values are successively 0.13 (forest), 0.19 (grassland), 0.24 (cultivated), 0.34 (garden) and $1.30 \mathrm{mg} \cdot \mathrm{kg}^{-1}$ (SUITMAs). Extreme values, in the 95 th percentile reaching $162 \mathrm{mg} \cdot \mathrm{kg}^{-1}$, were recorded for SUITMAs.

Total $\mathrm{Cu}$ concentrations also increased along the gradient of land use, except for cultivated topsoils $\left(14.0 \mathrm{mg} \cdot \mathrm{kg}^{-1}\right)$, which presented a lower median than grassland topsoils $\left(16.2 \mathrm{mg} \cdot \mathrm{kg}^{-1}\right)$ (Fig.7). No significant difference in median is observed between orchard and vineyard (63.6 $\left.\mathrm{mg} \cdot \mathrm{kg}^{-1}\right)$, garden $\left(38.5 \mathrm{mg} \cdot \mathrm{kg}^{-1}\right)$ and SUITMAs (43.3 $\mathrm{mg} \cdot \mathrm{kg}^{-1}$ ) topsoils. For the first three land uses, the median increased by 1.2 to 1.8 times from land use to land use, while there was a difference of 4.5 fold between cultivated agricultural soils and orchard and vineyards soils.

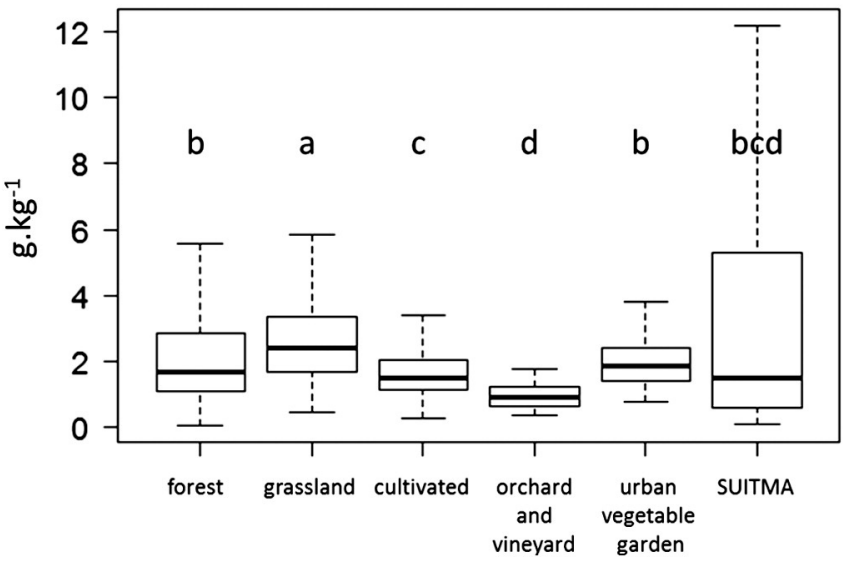

Fig. 3. Distribution of total nitrogen in French topsoils according to land use: forest ( $\mathrm{n}=$ 582), grassland ( $n=623)$, cultivated $(n=820)$, orchard and vineyard $(n=48)$, urban vegetable garden $(n=104)$ and SUITMA $(n=219)$. Band inside the box represent the median. Bottom and top of the box are the first and third quartiles. The whiskers indicate the lowest datum within 1.5 interquartile range of the lower quartile, and the highest datum within 1.5 interquartile range of the upper quartile. Lower case letters indicate significant differences between land use. 


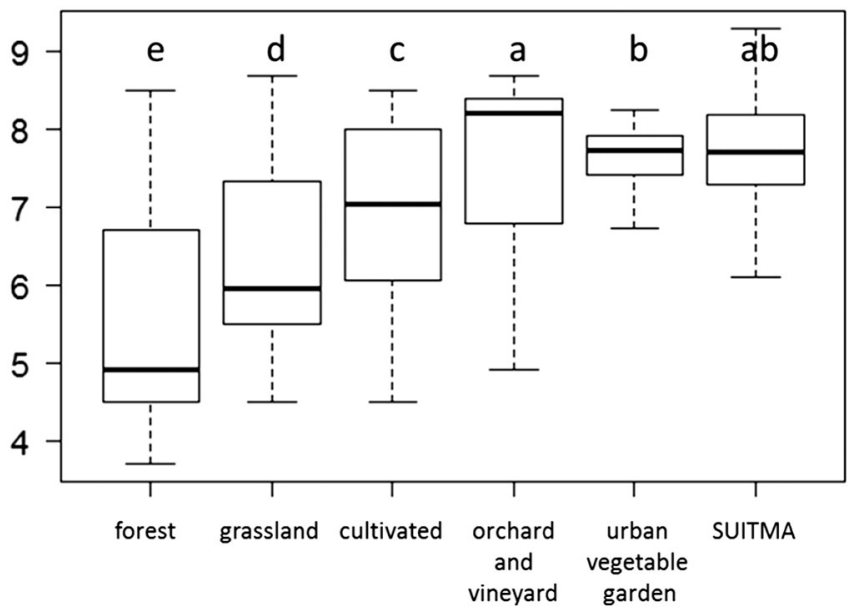

Fig. 4. Distribution of $\mathrm{pH}$ in French topsoils according to land use: forest $(\mathrm{n}=582)$, grassland ( $n=623)$, cultivated $(n=820)$, orchard and vineyard $(n=48)$, urban vegetable garden ( $n=104)$ and SUITMA $(n=249)$. Band inside the box represent the median. Bottom and top of the box are the first and third quartiles. The whiskers indicate the lowest datum within 1.5 interquartile range of the lower quartile, and the highest datum within 1.5 interquartile range of the upper quartile. Lower case letters indicate significant differences between land use.

SUITMA topsoils showed the highest median of total Ni content $\left(22.6 \mathrm{mg} \cdot \mathrm{kg}^{-1}\right)$, with no significant differences except for cultivated $\left(19.4 \mathrm{mg} \cdot \mathrm{kg}^{-1}\right)$ and forest $\left(15.5 \mathrm{mg} \cdot \mathrm{kg}^{-1}\right)$ topsoils (Fig.8). Differences between land uses were slight, with a maximum increase of 1.4 fold.

Medians of total $\mathrm{Pb}$ concentrations were lower in forest $\left(28.5 \mathrm{mg} \cdot \mathrm{kg}^{-1}\right), \quad$ grassland $\left(30.6 \mathrm{mg} \cdot \mathrm{kg}^{-1}\right), \quad$ cultivated $\left(25.4 \mathrm{mg} \cdot \mathrm{kg}^{-1}\right)$ and orchard and vineyard $\left(26.9 \mathrm{mg} \cdot \mathrm{kg}^{-1}\right)$ topsoils, with no significant difference except for agricultural cultivated soils (Fig.9). Significant differences are observed between these soils, gardens (74.6 $\mathrm{mg} \cdot \mathrm{kg}^{-1}$ ) and SUITMAs (415.1 $\mathrm{mg} \cdot \mathrm{kg}^{-1}$ ), which present significantly higher medians. In addition, SUITMAs presented more pronounced differences to other soils as medians are respectively 5.6 and 15 times lower in garden and orchard and vineyards, while the difference between these two soils is only 2.8 fold. Moreover, SUITMAs presented the widest distribution of values and $5 \%$ of total $\mathrm{Pb}$ concentrations were higher than $39,825 \mathrm{mg} \cdot \mathrm{kg}^{-1}$.

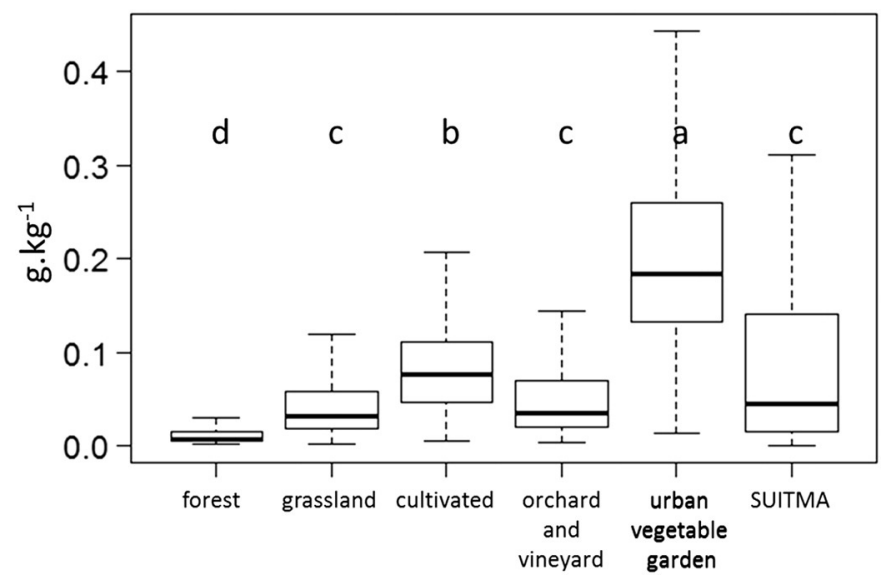

Fig. 5. Distribution of available phosphorus (Olsen method) in French topsoils according to land use: forest $(n=582)$, grassland $(n=623)$, cultivated $(n=820)$, orchard and vineyard $(n=48)$, urban vegetable garden $(n=104)$ and SUITMA $(n=173)$. Band inside the box represent the median. Bottom and top of the box are the first and third quartiles. The whiskers indicate the lowest datum within 1.5 interquartile range of the lower quartile, and the highest datum within 1.5 interquartile range of the upper quartile. Lower case letters indicate significant differences between land use.

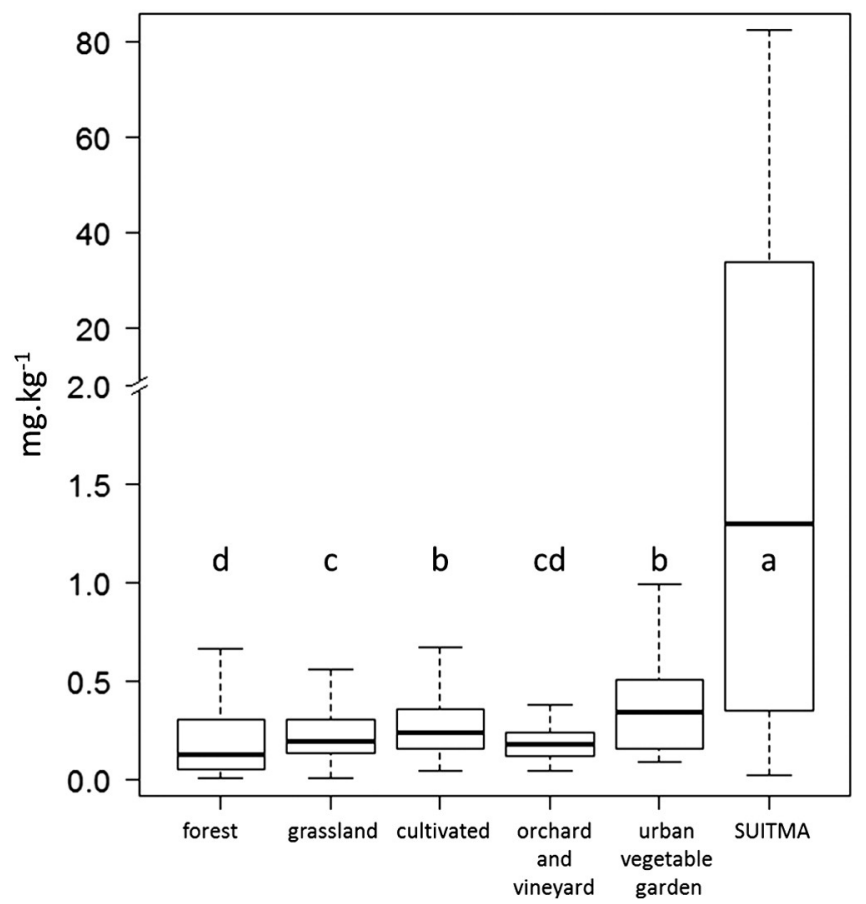

Fig. 6. Distribution of total cadmium in French topsoils according to land use: forest ( $\mathrm{n}=$ 582 ), grassland ( $n=623$ ), cultivated ( $n=820$ ), orchards and vineyard ( $n=48)$, urban vegetable garden $(n=104)$ and SUITMA $(n=261)$. Band inside the box represent the median. Bottom and top of the box are the first and third quartiles. The whiskers indicate the lowest datum within 1.5 interquartile range of the lower quartile, and the highest datum within 1.5 interquartile range of the upper quartile. Lower case letters indicate significant differences between land use.

Total Zn concentrations (median) significantly increased along the land use gradient, except for cultivated soils $\left(60.0 \mathrm{mg} \cdot \mathrm{kg}^{-1}\right)$, which present lower median than grassland soils (73.4 $\mathrm{mg} \cdot \mathrm{kg}^{-1}$ ) (Fig.10). Median concentrations for orchard and vineyard $\left(55.2 \mathrm{mg} \cdot \mathrm{kg}^{-1}\right)$ soils were not significantly different from the first three land uses. SUITMAs presented 5.9 times higher $\mathrm{Pb}$ values compared to orchards and vineyards, while the $\mathrm{Pb}$ median in gardens was only 2.4 times higher than orchards and vineyards. SUITMAs again presented the widest distribution of values with $5 \%$ of total $\mathrm{Zn}$ concentration were higher than $35,590 \mathrm{mg} \cdot \mathrm{kg}^{-1}$.

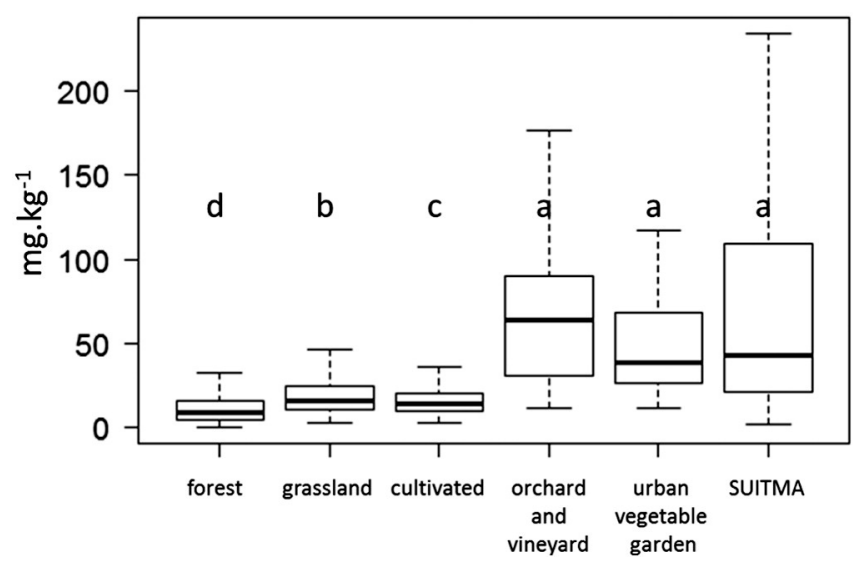

Fig. 7. Distribution of total copper in French topsoils according to land use: forest ( $\mathrm{n}=$ 582 ), grassland ( $n=623)$, cultivated $(n=820)$, orchard and vineyard $(n=48)$, urban vegetable garden $(n=104)$ and SUITMA $(n=238)$. Band inside the box represent the median. Bottom and top of the box are the first and third quartiles. The whiskers indicate the lowest datum within 1.5 interquartile range of the lower quartile, and the highest datum within 1.5 interquartile range of the upper quartile. Lower case letters indicate significant differences between land use. 


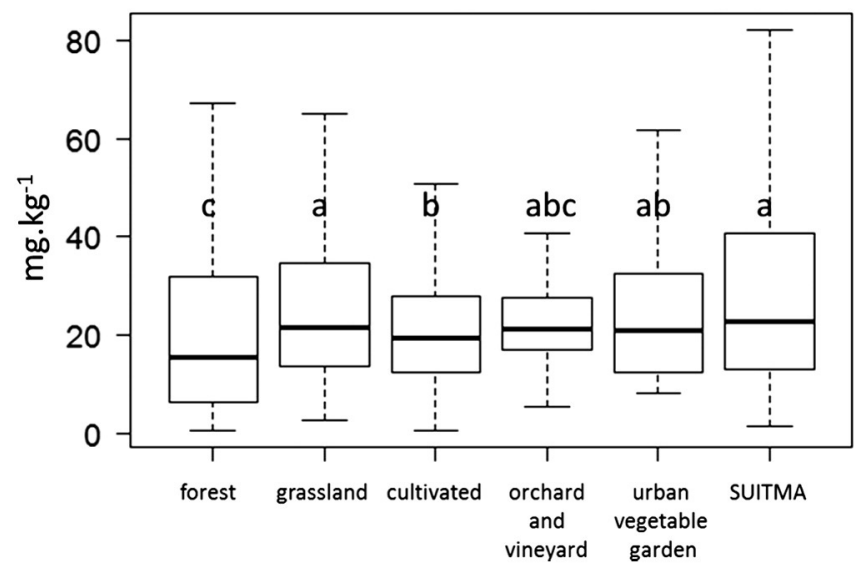

Fig. 8. Distribution of total nickel in French topsoils according to land use: forest ( $\mathrm{n}=$ $582)$, grassland $(n=623)$, cultivated $(n=820)$, orchard and vineyard $(n=48)$, urban vegetable garden $(n=104)$ and SUITMA $(n=261)$. Band inside the box represent the median. Bottom and top of the box are the first and third quartiles. The whiskers indicate the lowest datum within 1.5 interquartile range of the lower quartile, and the highest datum within 1.5 interquartile range of the upper quartile. Lower case letters indicate significant differences between land use.

\section{Discussion}

To our knowledge, no systematic national inventory has explored the extent to which soils under different and contrasting land uses present significantly different chemical characteristics. The results confirm the gradient introduced by Saby et al. $(2011,2008)$ for forest and various agricultural land uses in the RMQS network. The complementary approach we propose, using two additional databases, allows the detection of soil fertility and contamination differences across a wider range of land uses, including urban and industrial sites, which are not represented in the RMQS data because of the systematic $16 \mathrm{~km}^{2}$ grid. The concept of an anthropisation gradient is thus demonstrated and

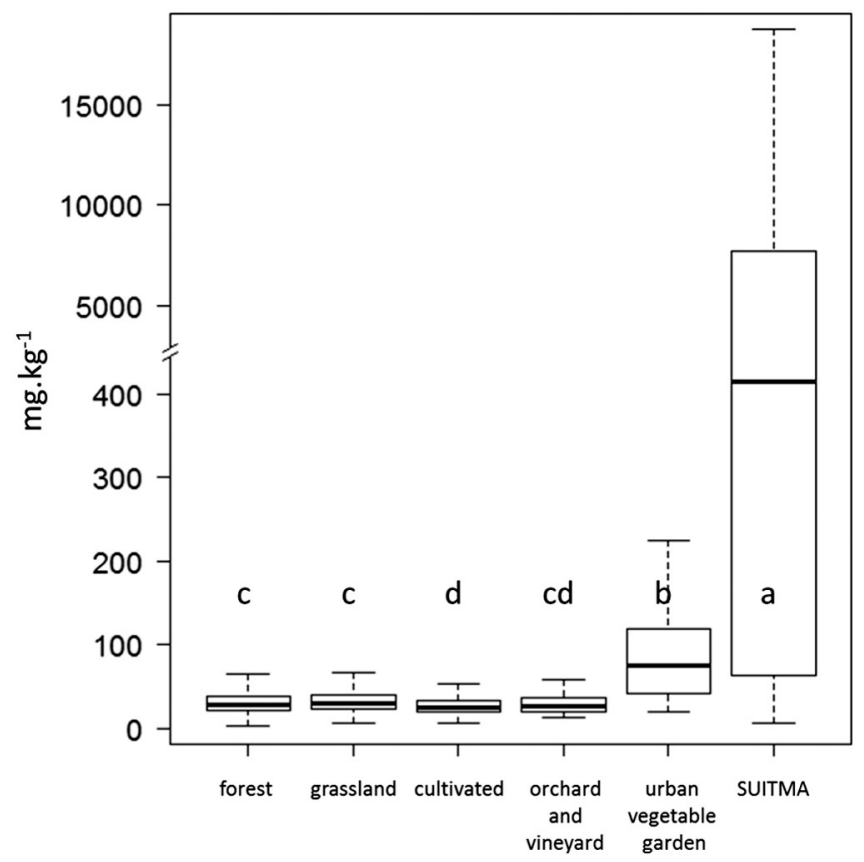

Fig. 9. Distribution of total lead in French topsoils according to land use: forest $(n=582)$, grassland ( $n=623)$, cultivated $(n=820)$, orchard and vineyard $(n=48)$, urban vegetable garden $(n=104)$ and SUITMA $(n=221)$. Band inside the box represent the median. Bottom and top of the box are the first and third quartiles. The whiskers indicate the lowest datum within 1.5 interquartile range of the lower quartile, and the highest datum within 1.5 interquartile range of the upper quartile. Lower case letters indicate significant differences between land use.

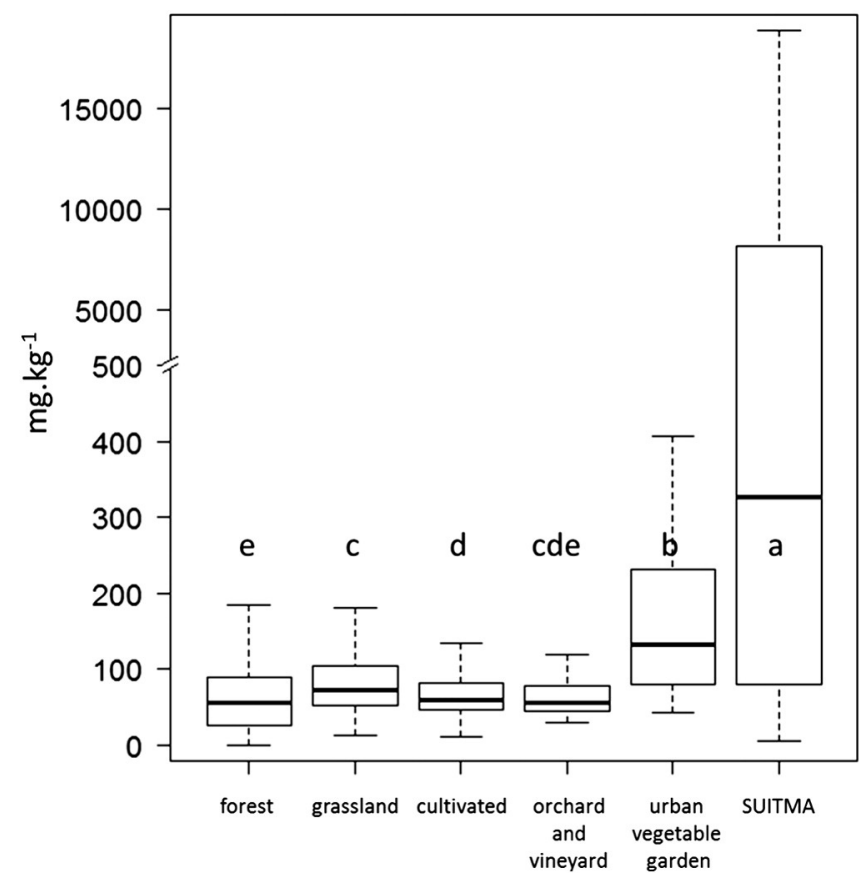

Fig. 10. Distribution of total zinc in French topsoils according to land use: forest $(n=582)$, grassland $(n=623)$, cultivated $(n=820)$, orchard and vineyard $(n=48)$, urban vegetable garden $(n=104)$ and SUITMA $(n=262)$. Band inside the box represent the median. Bottom and top of the box are the first and third quartiles. The whiskers indicate the lowest datum within 1.5 interquartile range of the lower quartile, and the highest datum within 1.5 interquartile range of the upper quartile. Lower case letters indicate significant differences between land use.

quantified through a comparison of all the topsoil characteristics. The results highlight the main characteristics of topsoils relating to the major land uses occurring in France. Soil characteristics are mainly significantly different from one land use to the other inside a continuum of soil fertility and contaminant parameters over the national soil mantle.

The results showed six different distribution patterns of soil characteristics as a function of land use. (1) Higher pH levels are found in anthropised soils than in forests soils. Soils cultivated for food production (cultivated, orchards and vineyards, garden soils) exhibit neutral or alkaline $\mathrm{pH}$ as a result of human input (e.g. lime). In urban and industrialised areas, alkalinisation is mainly induced by waste input and dust deposits (e.g. gravel, rubble, concrete) (Morel et al., 2005a,b; Rokia et al., 2014). (2) The addition of pesticides and fertilisers to soils (Belon et al., 2012; Saby et al., 2011) and atmospheric fallout from traffic induce metal contamination (El Khalil et al., 2008; Wong et al., 2006), which contributes to the gradual increase from forest land use to more anthropised land uses. Total $\mathrm{Cd}, \mathrm{Pb}$ and $\mathrm{Zn}$ concentration increases exponentially especially from (peri)urban contexts with differences between urban gardens and SUITMAs. This inorganic contamination is related to human activities like mining, the spreading of liquid and solid wastes, or building and road construction, which dramatically affect the composition of anthropogenic soils (Scharenbroch et al., 2005). (3) Two groups of land uses showed a contrasting total Cu concentration in topsoils: i) forest and agricultural soils, and ii) the soils of orchards, vineyards, gardens, and urban and industrial areas. For the latter, significantly higher concentrations of $\mathrm{Cu}$ in topsoils can be explained (i) by intensive plant health practices (orchards, vineyards, garden soils), and (ii) by the addition of contaminated wastes or byproducts to soils (urban and industrial areas); (4) available P increased along the anthropisation gradient (except for orchards and vineyards) and was highest in garden soils as a result of high inputs of fertilisers in vegetable gardens (Wivstad et al., 2005); (5) Total C and N in topsoils were the highest at both ends of the anthropisation gradient (forest $=$ 
grassland $>$ cultivated $>$ orchard and vineyard $<$ garden $=$ SUITMA). Except for SUITMAs, $\mathrm{C}$ and $\mathrm{N}$ concentrations are related to the incorporation of organic matter (forest litter or organic amendments in agriculture) and mineral fertilisers (agriculture, gardens). Enhanced C and $\mathrm{N}$ concentrations in SUITMAs result from the incorporation of wastes and by-products from human activity (e.g. composts, green wastes, sludge); (6) the last distribution pattern is specific to $\mathrm{Ni}$, whose concentration is not discriminated along the land use gradient. In previous studies, the relationship between total Fe and trace metals has allowed local variations in the natural pedo-geochemical background content to be detected and thus permitted the anthropogenic contamination to be estimated (Baize and Sterckeman, 2001). This ratio is constant in the environment and has frequently highlighted contaminations in $\mathrm{Cd}, \mathrm{Cu}, \mathrm{Pb}$ and $\mathrm{Zn}$. In contrast, generally speaking, $\mathrm{Ni}$ is correlated to the geochemical background (Bourennane et al., 2010; Sterckeman et al., 2006). Also, total Ni contaminations are very confined and are not detectable on a national scale (Gis Sol, 2011). In order to assess Ni contaminations, extractible Ni would provide more useful data. Probable contaminations have been reported in some areas of France (e.g. in the North), where values in extractible Ni are enhanced (Gis Sol, 2011).

The effect of anthropisation on soil quality generally increased nutrient concentrations (especially P) and soil contamination with metals (e.g. Pb). Cu contamination even occurred in soils dedicated to food production (in orchards, vineyards and gardens). If anthropogenic soils are contaminated with trace metals, sometimes showing extreme anomalies, these topsoils are mainly the most alkaline ones and present high organic matter concentrations, limiting the mobility and availability of metals. A study previously conducted in allotments and vegetable gardens has shown that food grown in urban areas presented minimal risk except for highly exposed individuals, especially infants (Hough et al., 2004). In contrast, some anthropogenic soils included in SUITMAs have a very acidic $\mathrm{pH}$ with high heavy metal content, which could involve risk for the human health.

A better knowledge of topsoil quality and its dependence on current land use must therefore help in the management and preservation of the soil mantle. For this purpose, $\mathrm{Cu}, \mathrm{Pb}$ or $\mathrm{Zn}$, $\mathrm{P}_{\text {Olsen }}$ concentrations and $\mathrm{pH}$ levels could be selected as indicators. More than $\mathrm{C}$ or $\mathrm{N}$, the main difference between topsoils in forests and grasslands is induced by $\mathrm{pH}$, which is more acidic in forests $($ mostly $<5)$ than in grasslands ( $50 \%$ of topsoils have a pH between 5 and 6 ). Cultivated soils present an overfertilisation in $\mathrm{P}$ and a neutral $\mathrm{pH}$. Topsoils in orchards and vineyards are characterised by a high content in $\mathrm{Cu}$, a neutral $\mathrm{pH}$ and low content in $\mathrm{P}_{\mathrm{Olsen}}$. In garden soils, all parameters are discriminant due to their high values. A subfertilisation in phosphorus is very characteristic of garden topsoils. Finally, SUITMA topsoils are mostly characterised by high contents in total $\mathrm{Cu}, \mathrm{Pb}$ and $\mathrm{Zn}$. Others parameters are not very discriminant due to the huge variability among SUITMAs. In fact, for SUITMAs, the presence of extreme values, which are usually considered as outliers, can be considered as an indicator.

Among SUITMAs, there seems to be distinct influences of anthropisation on urban soil characteristics, induced by the type of urban land use. As well as urban vegetable gardens, which were studied separately from SUITMAs, a future study would be needed to discriminate the different industrial and urban land uses included in this group.

\section{Conclusion}

Our results show a gradient of soil anthropisation from forest, agriculture-grassland, agriculture-cultivated, orchards and vineyards, urban vegetable gardens to urban, industrial, traffic, mining and military areas with an increase of metal contamination in $\mathrm{Cd}, \mathrm{Cu}, \mathrm{Pb}$ and $\mathrm{Zn}$, in $\mathrm{pH}$ and available $\mathrm{P}$. In contrast, land use has no effect on topsoil Ni concentration. For C and N, changes are mostly induced by cultivation. An increase in $\mathrm{C}$ is observed in garden soils which are intensively cultivated, and a decrease is observed in cultivated, vineyard and orchard soils. $\mathrm{Cu}$,
$\mathrm{Pb}, \mathrm{P}_{\mathrm{Olsen}}$ concentrations and $\mathrm{pH}$ levels could be selected as indicators of the anthropisation gradient.

Our study illustrates the value of aggregate databases concerning soil geochemical characteristics -even with distinct distributions approaches- in furthering our knowledge of soil quality.

\section{Acknowledgements}

This work was supported by the French Scientific Group of Interest in Soils "GIS Sol" involving the French Ministry for Ecology, Sustainable Development and Energy (MEEDDAT), the French Ministry of Agriculture (MAP), the French Agency for Environment and Energy Management (ADEME), the Institute for Research and Development (IRD), the National Institute of Geographic (IGN) and the National Institute for Agronomic Research (INRA) (www.gissol.fr) (RMQS) and by the French National Agency of Research (ANR) (JASSUR research project; ANR12-VBDU-0011). The authors wish to thank Dr Louis Florentin for his major contribution on the work on SUITMAs, the technical staff of the LSE and especially Alain Rakoto and Jean-Claude Bégin, the gardeners and all the partners involved in the JASSUR program for their substantial help.

\section{References}

Arrouays, D., Jolivet, C.C., Boulonne, L., Bodineau, G., Saby, N.P.A., Grolleau, E., 2002. A new initiative in France: a multi-institutional soil quality monitoring network. Comptes Rendus Acad. Agric. Fr. 88, 93-105.

Arrouays, D., Saby, N.P.A., Thioulouse, J., Jolivet, C., Boulonne, L., Ratié, C., 2011. Large trends in French topsoil characteristics are revealed by spatially constrained multivariate analysis. Geoderma 161, 107-114.

Baize, D., Sterckeman, T., 2001. Of the necessity of knowledge of the natural pedogeochemical background content in the evaluation of the contamination of soils by trace elements. Sci. Total Environ. 264, 127-139.

Belon, E., Boisson, M., Deportes, I.Z., Eglin, T.K., Feix, I., Bispo, A.O., Galsomies, L., Leblond S., Guellier, C.R., 2012. An inventory of trace elements inputs to French agricultural soils. Sci. Total Environ. 439, 87-95.

Bossard, M., Feranec, J., Otahel, J., 2000. CORINE Land Cover Technical Guide - Addendum 2000 (Publication No. Technical Report 4). Copenhagen, European Environment Agency (EEA).

Bourennane, H. Douay, F., Sterckeman, T., Villanneau, E., Ciesielski, H., King, D., Baize, D. 2010. Mapping of anthropogenic trace elements inputs in agricultural topsoil from Northern France using enrichment factors. Geoderma 157, 165-174.

Bullock, P., Gregory, P.J. (Eds.), 1991. Soils in the Urban Environment. Blackwell Publishing Ltd., Oxford, UK.

Chenot, E.-D., Douay, F., Dumat, C., Pernin, C., Pourrut, B., Schwartz, C. (coord.)., 2012 Jardins potagers: terres inconnues? EDP Sciences, Les Ulis.

Crößman, G., Wüsteman, M., 1992. Belastungen in Haus- und Kleingärten durch anorganische und organische Stoffe mit Schadstoffpotential. Forschungsbericht 1160868. Umweltforschungsplan des Bundesministers für Umwelt, Naturschutz und Reaktorsicherheit $47 \mathrm{pp}$.

De Kimpe, C.R., Morel, J.-L., 2000. Urbain soil management: a growing concern. Soil Sci. $165,31-40$.

Dewaelheyns, V., Elsen, A., Vandendriessche, H., Gulinck, H., 2013. Garden management and soil fertility in Flemish domestic gardens. Landsc. Urban Plan. 116, 25-35.

Douay, F., Pruvot, C., Roussel, H., Ciesielski, H., Fourrier, H., Proix, N., Waterlot, C., 2008. Contamination of urban soils in an area of Northern France polluted by dust emissions of two smelters. Water Air Soil Pollut. 188, 247-260.

El Khalil, H., Schwartz, C., Elhamiani, O., Kubiniok, J., Morel, J., Boularbah, A., 2008. Contribution of technic materials to the mobile fraction of metals in urban soils in Marrakech (Morocco). J. Soils Sediments 8, 17-22.

El Khalil, H., Schwartz, C., El Hamiani, O., Kubiniok, J., Morel, J.L., Boularbah, A., 2013. Distribution of major elements and trace metals as indicators of technosolisation of urban and suburban soils. J. Soils Sediments 13, 519-530.

Ellis, E., Pontius, R., 2012. Land-use. In: Cutler, J. (Ed.), Encyclopedia of Earth, Environmental Information Coalition. National Council for Science and the Environment, Cleveland.

Gis Sol, 2011. Synthèse sur l'état des sols de France. GIS Sol, Paris.

Hough, R.L., Breward, N., Young, S.D., Crout, N.M.J., Tye, A.M., Moir, A.M., Thornton, I., 2004. Assessing potential risk of heavy metal exposure from consumption of homeproduced vegetables by urban populations. Environ. Health Perspect. 112, 215-221.

INSEE, 1993. Conditions de vie des ménages.

Lefort, C., 2009. Contribution à la définition et à la classification des Technosols. INPL Nancy.

Lefort, C., Schwartz, C., Florentin, L., Gury, M., Morel, J., 2006. Determination of model substrates for the study of the pedogenesis of Technosols. Workshop on Modelling of Pedogenesis.

McDonald, L.M., Balasko, J.A., 2003. Temporal trends in Ca, Mg and $\mathrm{K}$ concentrations of grassland and garden soils in West Virginia, U.S.A. between 1986 and 1999. Water Air Soil Pollut. 146, 351-363. 
Mitchell, R.G., Spliethoff, H.M., Ribaudo, L.N., Lopp, D.M., Shayler, H.A., Marquez-Bravo, L.G., Lambert, V.T., Ferenz, G.S., Russell-Anelli, J.M., Stone, E.B., McBride, M.B., 2014 Lead $(\mathrm{Pb})$ and other metals in New York City community garden soils: factors influencing contaminant distributions. Environ. Pollut. 187, 162-169.

Morel, J.L., Schwartz, C., Florentin, L., de Kimpe, C., 2005a. Urban soils. In: Hillel, D. (Ed.) Encyclopedia of Soils in the Environment. Elsevier, Oxford, pp. 202-208.

Morel, J., Schwartz, C., Florentin, L., 2005b. Urban soils. Encycl. Soils Environment 335, 202-208.

Morel, J.L., Chenu, C., Lorenz, K., 2014. Ecosystem services provided by soils of urban, industrial, traffic, mining, and military areas (SUITMAs). J. Soils Sediments 1-8.

Nehls, T., Jozefaciuk, G., Sokołowska, Z., Hajnos, M., Wessolek, G., 2006. Pore-system characteristics of pavement seam materials of urban sites. J. Plant Nutr. Soil Sci. 169 $16-24$.

Norra, S., Lanka-Panditha, M., Kramar, U., Stüben, D., 2006. Mineralogical and geochemical patterns of urban surface soils, the example of Pforzheim, Germany. Appl. Geochem. 21, 2064-2081.

Putegnat, A., 2001. Les jardins familiaux : comment une innovation sociale peut engendrer des risques pour l'homme et l'environnement. Ann. Mines Responsab. Environ. 24, 83-90.

Rokia, S., Séré, G., Schwartz, C., Deeb, M., Fournier, F., Nehls, T., Damas, O., Vidal-Beaudet L., 2014. Modelling agronomic properties of Technosols constructed with urban wastes. Waste Manag. 34, 2155-2162.

Saby, N.P.A., Bellamy, P.H., Morvan, X., Arrouays, D., Jones, R.J.A., Verheijen, F.G.A., Kibblewhite, M.G., Verdoodt, A., Üveges, J.B., Freudenschuß, A., Simota, C., 2008. Will European soil-monitoring networks be able to detect changes in topsoil organic carbon content? Glob. Chang. Biol. 14, 2432-2442.
Saby, N.P.A., Thioulouse, J., Jolivet, C.C., Ratié, C., Boulonne, L., Bispo, A., Arrouays, D., 2009. Multivariate analysis of the spatial patterns of 8 trace elements using the French soil monitoring network data. Sci. Total Environ. 407, 5644-5652.

Saby, N.P.A., Marchant, B.P., Lark, R.M., Jolivet, C.C., Arrouays, D., 2011. Robust geostatistical prediction of trace elements across France. Geoderma 162, 303-311.

Scharenbroch, B.C., Lloyd, J.E., Johnson-Maynard, J.L., 2005. Distinguishing urban soils with physical, chemical, and biological properties. Pedobiologia 49, 283-296.

Schroeder, W.H., Dobson, M., Kane, D.M., Johnson, N.D., 1987. Toxic trace elements associated with airborne particulate matter: a review. JAPCA 37, 1267-1285.

Schwartz, C., 1993. Facteurs de qualité des sols de jardins de l'Est-mosellan. Institut National Polytechnique de Lorraine (INPL) Ecole Nationale Supérieure d'Agronomie et des Insdustries Alimentaires (ENSAIA).

Schwartz, C., Florentin, L., Charpentier, D., Muzika, S., Morel, J., 2001. Le pédologue en milieux industriels et urbains. I. Sols d'une friche industrielle. Etude Gest. Sols 8, 135-148.

Sterckeman, T., Douay, F., Baize, D., Fourrier, H., Proix, N., Schvartz, C., 2006. Trace elements in soils developed in sedimentary materials from Northern France. Geoderma 136, 912-929.

Vitousek, P.M., Mooney, H.A., Lubchenco, J., Melillo, J.M., 1997. Human domination of earth's ecosystems. Science, New Series 277, 494-499.

Wivstad, M., Dahlin, A.S., Grant, C., 2005. Perspectives on nutrient management in arable farming systems. Soil Use Manag. 21, 113-121.

Wong, C.S.C., Li, X., Thornton, I., 2006. Urban environmental geochemistry of trace metals. Environ. Pollut. 142, 1-16. 